\title{
Pedagogical Consciousness Formation of Future University Educators in the Process of Teaching English
}

\author{
Natalia Sidash', Marina Roganova ${ }^{2}$, Viktoriia Domina ${ }^{3}$, Lesia Victorova ${ }^{4}$, Maxim Roganov $^{4}$, \\ Valentyna Miroshnichenko ${ }^{5}$, \\ ${ }^{1}$ Department of Natural, Social and Humanitarian Sciences, Institute of Chemical Technologies of the Volodymyr Dahl East \\ Ukrainian National University, Ukraine \\ ${ }^{2}$ Department of Theory and Methods of Preschool Education, Municipal Institution «Kharkiv Humanitarian-Pedagogical Academy» \\ of Kharkiv Regional Council, Ukraine \\ ${ }^{3}$ Department of Romance and Germanic Languages and Translation, National University of Life and Environmental Sciences of \\ Ukraine, Ukraine \\ ${ }^{4}$ Department of Social work and Social Rehabilitation, National University of Life and Environmental Sciences of Ukraine, Ukraine \\ ${ }^{5}$ Faculty of Foreign Languages and Humanities, Bohdan Khmelnytskyi National Academy of the State Border Guard Service of
} Ukraine, Ukraine

Received January 11, 2020; Revised February 27, 2020; Accepted March 12, 2020

Copyright $\bigcirc 2020$ by authors, all rights reserved. Authors agree that this article remains permanently open access under the terms of the Creative Commons Attribution License 4.0 International License

\begin{abstract}
The research is devoted to the scientific substantiation of the process of pedagogical consciousness formation of university educators in the process of teaching English, determination of the level of their pedagogical consciousness formation, developing an organization and methodological conditions for pedagogical consciousness formation, determination of the optimal methods of its diagnostics, and further implementation of organization and methodological conditions in the educational process of higher school. The research represents the organization and methodological conditions for the pedagogical consciousness formation of the university educators in the process of teaching English: the training program of theoretical knowledge on the nature and the structure of pedagogical consciousness; ensuring the active learning activities of students to develop the skills of practical application of important pedagogical tools and methodologies; the use of interactive teaching methods to create a learning environment that contributes to the assimilation of moral, ethical and cultural values of pedagogical activity as well as mastering of the self-assessment skills and self-control of the level of pedagogical consciousness formation. The authors define the criteria (content and activity, motivation and value, evaluation and reflection) that provide the effectiveness and optimality of the pedagogical consciousness formation. The positive dynamics of pedagogical consciousness formation of university educators is achieved through the use of the special course "Self-reflection of pedagogical consciousness" which includes pedagogical technologies, interactive and
\end{abstract}

moderation techniques, creative exercises in the process of teaching English. The monitoring analysis of the results of the formative experiment proves that the experimental group, in contrast to the control group, has a higher level of pedagogical consciousness formation.

Keywords Pedagogical Consciousness, Future University Educators, Teaching English, Pedagogical Technologies

\section{Introduction}

Social and economic changes contribute to the reform of the system of higher education. The processes of reforming higher education are characteristic for many countries of the world because innovation processes have no borders. "Education is one of the most powerful ways of achieving SDG 3 (Sustainable Development Goals 3: ensure healthy lives and promote well-being for all at all ages) and the benefits to future generations" (Steering Committee, 2017, p. 2). "Education in a globalized world is increasingly putting emphasis on the importance of values, attitudes and communication skills as a critical complement to cognitive knowledge and skills" (UNESCO, 2013, p.1). The higher school plays a decisive role in the education of the intellectual resources (Bak, 2018, Neamtu, 2015), spirituality, morality and culture of people; training highly qualified scientific personnel (Albulescu, 2014, Dumciuviene, 2015, Plögera, Scholla, \& Seifert, 2018), which will lead to the strengthening of 
state and its development. And only a competent, honest and responsible university educator, with his clear civic position, pedagogical consciousness, and self-consciousness, is capable of renewing society, developing its economy and culture.

The 2015 Incheon Declaration and the Education 2030 Framework for Action set out a new vision for education for the next fifteen years. "By 2030, substantially increase the supply of qualified teachers, including through international cooperation for teacher training in developing countries, especially least developed countries" (UNESCO, 2015, p. 21); "improve the quality of teacher training (pre-service and in-service) and provide all teachers with quality pre-service education and continuous professional development and support" (UNESCO, 2015, p. 55); "teachers and education support personnel can: use their professionalism and commitment to ensure that students learn; bring classroom realities to the forefront of policy dialogue, policy-making and planning and provide a bridge between policy and practice, contributing their experiences as practitioners and their collective insights and expertise to overall policies and strategies; promote inclusion, quality and equity, and improve curricula and pedagogy" (UNESCO, 2015, p. 58).

Outcome document of the Technical Consultation on Global Citizenship Education stresses on equipping learners with deep knowledge of global issues and universal values (justice, equality, dignity and respect), critical thinking, social skills (empathy, conflict resolution), communicative skills, behavioral capacities to act collaboratively, responsibly (UNESCO, 2013).

EU agenda for higher education specifies that "higher education institutions are often not contributing as much as they should to innovation in the wider economy, particularly in their regions" (European Commission [EC], 2017 , p. 4.) and recognizes the importance "to equip students with the ability to understand new concepts, think critically and creatively and act entrepreneurially to develop and apply new ideas" (EC, 2017, p. 8). Scott (2015) argues that "formal education must be transformed to enable new forms of learning that are needed to tackle complex global challenges". This is inextricably linked with the question of "what knowledge and abilities teachers should acquire in order to achieve effective professional development and "what is needed to make the development of appropriate competencies possible" (Bürgener \& Barth, 2018, p. 821; Archibald, Coggshell, Croft, \& Goe, 2011).

The research hypothesis is that pedagogical consciousness formation of future university educators in the process of teaching English will be effective under a certain organization and methodical conditions.

\subsection{The Aim}

The objective of this research is to study the organization and methodological conditions of pedagogical consciousness formation of future university educators in the process of teaching English.

\subsection{Tasks}

1. On the basis of the analysis of domestic and foreign scientific literature to uncover the essence of the concept of "pedagogical consciousness" and its structural components;

2. To define the criteria and indicators for the formation of the pedagogical consciousness of future university educators;

3. To define the organization and methodological conditions of pedagogical consciousness formation of future university educators in the process of teaching English and to test its effectiveness.

When studying research papers of scientists, the concept of "consciousness", "pedagogical consciousness" and "professional consciousness" was considered. Analyzing their work, one can notice that the authors focus only on certain aspects of the given phenomenon, which does not allow creating a holistic view of the formation or development of pedagogical consciousness of future university educators. Summarizing and systematizing existing definitions and taking into account the diversity of opinions of scientists regarding the concept under study, we can conclude that "pedagogical consciousness" is a holistic, dynamic personal formation that includes professional knowledge and skills, personal experience of the educator and professionally important qualities, pedagogical values awareness, the formation of value orientations and self-development motives, positive valuable and emotional attitude towards oneself as a specialist and pedagogical activity, the ability to control personal emotional and mental state, creative and pedagogical activity, goal-setting, professional orientation, ability to reflection (Sidash, 2017, p. 21).

The process of pedagogical consciousness formation takes place on the theoretical and practical levels with the acquisition of its qualitative characteristics (spiritual and moral qualities, the culture of emotions and dialogue, the ability to creativity and innovation, self-reflexivity) and personal qualities of the educator (cognitive abilities, constructive and intuitive thinking, benevolence, optimism, creative orientation and positive attitude to pedagogy activities, self-awareness, tolerance) (Sidash, 2017, p. 101).

"At the same time, pedagogical consciousness formation depends on the influence of objective and subjective, external (social, cultural and professional environment, educational and pedagogical activity, pedagogical communication, the teacher-student cooperation, which determine the internalization of social norms, rules, values, and morals), and internal conditions (the level of professional knowledge, skills, value 
orientations, professionally significant qualities, interest in pedagogical activity, professional self-esteem, cognitive development needs, motivation, self-regulation, professional activity)“"(Sidash, 2017, p. 101).

For successful pedagogical consciousness formation in the process of teaching English, certain conditions must be created: acquisition of pedagogical knowledge and professional skills; spiritual, moral and cultural values; the essence of the key concepts: "consciousness", "professional consciousness", "pedagogical consciousness"; the factors that promote its development; self-reflection, goal-setting; mastering self-assessment diagnostic methods.

\section{Materials and Methods}

\subsection{Literature Review}

Analyzing a large number of scientific papers, we can argue that the problem of consciousness is central to mental phenomena. Consciousness is often used to describe the state of being awake and aware, thoughts, sensations, perceptions, moods, emotions, and dreams (Sirswal, 2009), it is also defined as the subject of experiencing or feeling (Libet, 1988), awareness, knowledge, an active state of thinking (Radd \& Macey, 2013). The authors describe human consciousness as an embodied experience that emerges from a complex relationship between the biological and the phenomenological. They argue that consciousness is an emergent property of biology, culture and human beings develop self-awareness of their own minds by becoming cognizant of other minds (Sumara, Luce-Kapler \& Iftody, 2013 , p. 228). We can conclude that consciousness is a mental phenomenon shaped by cultural and philosophical aspects.

Critical consciousness - "internal cognitive activity or state of being" (McDonough, \& Kathleen, 2015, p. 47), "an active state of seeking to identify the beliefs and language that obscure systemic inequities", it is as a tool in professional learning and offers guidance to educators who are looking to develop critical consciousness by describing a critical approach (Radd \& Macey, 2013).

Enns and Shapovalova (2015) define professional consciousness of a teacher as "self-consciousness of the person who is actively involved in productive work and who uses this work as the chief means of self-fulfillment and his dignity" (p. 387). The consciousness of preservice teachers is also defined as "a complex of cognitive and effective learning" (Kalsoom \& Khanam, 2017, p. 1301).

Blaškováa, Blaškoa, and Kucharpíkováa (2014) represent a summary of key professional and personal skills/talents and behavioral patterns of an individual (professional, educational, motivational and communicational, personal, science, research, publication competence). "They form the basis of any proficient working behavior, and the level of their maturity is crucial for the successful performance of the profession concerned" (Blaškováa, Blaškoa, and Kucharpíkováa, 2014, p. 457).

Thus, Duta et al. (2015) determine the essential components of an effective teacher "humor, honesty, empathy, more democratic than autocratic able to create the report with students, both individually and in groups, open, spontaneous adaptable to change" (Duta, 2015, p. 1229).

Scientists highlight "the importance of improving future teacher education on the basis of an appropriate formation vision that values: awareness, reflection, ethical responsibility and appropriate professional behavior" (Serdenciuc, 2015, p. 966), "interaction and cooperation, emotionally, relationally and morally sound pedagogical practices" (Kostiainen, et al., 2018, p. 66), reflective skills (Kalsoom \& Khanam, 2017), creativity pedagogy (Liao, et al., 2018), "through awareness-raising of and critical reflection on teaching behavior" (Ebadi \& Gheisari, 2016, p. 1), social interaction, internalization, mediation, psychological systems (Shabani, 2016). The researchers state that "developing personal and professional consciousness about racial, cultural, and ethnic diversity should be a major component of preservice teacher education" (Gay \& Kirkland, 2003, p. 181). The authors also emphasize the contribution of Art Education courses to teacher professional education (Kuyumcu, 2012). Sumara, Luce-Kapler, and Iftody (2013) argue that "literary experiences create productive mind-reading practices that contribute to the ongoing development and emergence of consciousness and, as such, are important for education" (p. 228). Sharma, Ahuja, and Satsangee (2016) prove the rise in consciousness level with the rise in the educational level at the University (p. 91).

Some scholars state that to get students absorbed in a foreign language environment is a crucial task of every instructor who is anxious to get them engaged in learning environment and make them excited about a topic. They are also conscious of adapting students to a new content of a lesson as well as to 'break ice' in communication and get them motivated for learning from the start. (Karpushyna, Bloshchynskyi, Nakonechna, Skyba, 2019).

"Teachers' ability to use English for academic purposes is one of the crucial factors of their competence. A fundamental requirement for university educators is their high academic English proficiency, attainable through continued language training" (Margić \& Vodopija-Krstanović, 2018, p. 31). Another important issue is the changing role of the university educator for teaching through English medium instruction (EMI) and how an educator should acquire an appropriate level of English to teach through EMI (Dearden, 2014) due to its expansion primarily in higher education (Dearden \& Macaro, 2016). 


\subsection{Theoretical Analysis of the Problem}

Our analysis of the research and theory in this field revealed that the pedagogical consciousness formation has not been addressed in a comprehensive way. Most of the work are devoted to the theory of the problem and concern only some aspects of the pedagogical consciousness formation. Meanwhile, the given problem is a polemical one. Researchers consider the components of pedagogical consciousness and the process of the pedagogical consciousness formation in different ways. Analyzing existing definitions, we consider "pedagogical consciousness" as a complex, integral, multilateral, multi-level reflection and transformation of the psychological, professional, personal qualities of an educator, which are certain to affect the pedagogical interaction and the effectiveness of the educational process as a whole.

We can also conclude that consciousness makes it possible to reflect reality, to foresee the future, and on this basis to create and change the world through the practical activity. That is why it becomes obvious to consider pedagogical consciousness as a condition for the effective pedagogical activity, on which positive changes not only in education but also in all spheres of society depend.

We consider the cultural environment of higher educational institutions, which influences the process of development of new cultural entities, to play a key role in the pedagogical consciousness formation. The elements of the cultural environment are the unique relationships between students and educators, which are aimed at the creative development of the individual, creating a special way of life with inherent spirituality, morality, the culture of feelings, cognitive activity, initiative, creativity, etc.

The use of methodological tools of cognition should include a set of approaches (systemic, anthropological, axiological, cultural, personal and activity, procedural and dynamic); acquisition of pedagogical consciousness' qualitative characteristics and personal qualities of the educator, self-reflection; harnessing of self-assessment diagnostic methods promote high-level pedagogical consciousness formation.

\subsection{Participants}

179 masters of V.N. Karazin Kharkiv National University, Donbas State Pedagogical University, and Institute of Chemical Technologies of the Volodymyr Dahl East Ukrainian National University, Yuriy Fedkovych Chernivtsi National University, took part in the experimental work. Masters of the following specialities: elementary education, psychology, music art, preschool education, practical psychology, higher education pedagogy, psychology, geology, hydrogeology, geology of oil and gas, geography, geography of recreation and tourism, economic and social geography, chemical technologies of organic substances, equipment of chemical industries and enterprises of building materials were involved in the research. 90 masters were in the experimental group (EG); 89 masters were in the control group (CG). In contrast to the control group where a regular ESP curriculum was taught, we apply the organization and methodical conditions of the pedagogical consciousness formation of future university educators in the process of teaching English in the experimental group.

\subsection{Research Procedure}

Each of the criteria of pedagogical consciousness is characterized by its specific indicators, which predetermine the realization of pedagogical consciousness in the educational activity. This division is arbitrary since these criteria and their indicators are indivisible in real life. They interact, complement each other, cause and exist in one another.

In addition, we distinguish the main characteristics of the pedagogical "consciousness (intellectuality, spirituality, morality, the culture of feelings, reflexivity, creativity, dialogue), which determine the inner depth of the pedagogical consciousness of the future university educator and its essence" (Sidash, 2017, p. 100).

We consider the process of pedagogical consciousness formation in the context of various principles of personality formation of an educator: anthropological, axiological, cultural and logical, systemic, personal and active, process and dynamic. The set of these scientific principles allows organizing the study of the process of pedagogical consciousness formation of the future university educator, as a process of its structural and dynamic development at different stages of higher education, identifying the internal and external factors that provide the success and effectiveness of its formation.

In developing the scientific and methodical tool to assess the level of pedagogical consciousness formation we used the fragments of known test methods adapted for the purpose of the research as well as author diagnostic methods according to the content and activity criterion: expert assessment of future university educators' professional knowledge, practical skill questionnaire, author diagnostic methods to identify the students' perceptions of the concept of "pedagogical consciousness", the significance of characteristics of pedagogical consciousness, the knowledge of healthy psychological climate formation, self-assessment test of the level of pedagogical consciousness; motivation and value criterion: the humanistic orientation test (Friedman, \& MacDonald, 2006), the expert and self-assessment test to study the professionally important qualities, the questionnaires measuring spiritual needs (Bryant, Wickliffe, Mayhew \& Behringer 2009), motives of education and pedagogical activity (Abraham, Shirrell, Downs-Tepper, \& Chakravarthy, 2015), motives of raising the level of 
pedagogical consciousness, the emotion and value relation to oneself and one's education and profession oriented activity, the expert and self-assessment test to study the professionally important qualities of the future university educators; the evaluation and reflection criterion: expert and self-esteem test, career aspiration test.

We used the scientific and methodical tool as the single complex that is due to the pedagogical consciousness complicated structure and a wide range of indicators that we can fix and assess (qualitatively and quantitatively) and also analyze the relevant criteria formation, it provided the control of the level of pedagogical consciousness formation on the principal indicators. The use of the listed methods as the complex is determined by the nature of pedagogical consciousness as an integrated system.

The control experiment includes carrying out the diagnostic study of control and experimental groups in order to identify the dynamics of pedagogical consciousness formation based on the results of the approbation of the organization and methodical system in the process of teaching English.

The objective of the formative experiment is to check the effectiveness of organizational and methodological conditions of pedagogical consciousness formation of future university educators in the process of teaching English, namely: the training program of theoretical knowledge on the nature and the structure of pedagogical consciousness; ensuring the active learning activities of students to develop the skills of practical application of important pedagogical tools and methodologies; the use of interactive teaching methods to create a learning environment that contributes to the assimilation of moral, ethical and cultural values of pedagogical activity as well as the mastering of the self-assessment skills and self-control of the level of pedagogical consciousness formation.

We realized the organizational and methodological conditions of pedagogical consciousness formation of future university educators through the application of the special course "Self-reflection of pedagogical consciousness" and the diagnostic complex. This special course corresponds to the content and the structure of the pedagogical consciousness and provides the formation of key elements of pedagogical consciousness (knowledge, skills, values, and personal qualities). The diagnostic complex performs two functions in the formative experiment. It ensures future university educators' acquisition of the knowledge of self-diagnosis and self-control within the system and monitoring the effectiveness of the pedagogical consciousness formation during the experimental work.

The effectiveness of this special course was facilitated by such interactive learning technologies of education process organization: moderated seminars, a lecture-dialogue, workshops, quests, "inverted" lectures, seminars with training sessions, creative tasks, problem issues, discussions, multi-media tools, role games, reports, work with the scientific information sources, works of art and folk art, creative exercises and competitions, polls which provided various types of students' learning activities. The content of the special course includes 10 modules corresponding to the key elements of the pedagogical consciousness. The practical part of the author special course was aimed at the methodological training of educators for the use of pedagogical technology in their pedagogical practice. For instance, the class on the theme "University educator in the context of modern requirements to higher education" has the following plan: 1 . The image and professional qualities of the university educator: this module was presented by students in the form of self-presentation of the image of a future educator using information and communication technologies. 2. Training session on the acquisition of professional values: the training session assumes that the moderator arranges participants to the circle, giving them a round subject he suggests handing the subject from hand to hand, to formulate the motives of choosing the profession of an educator. 3. Discussion of the parable "Desirable is very near". Creation an ideal university educator portrait: writing a composition with a subsequent reflection of personal values. 4. Watching the fragment of Peter Weir's film "Dead Poets Society" with further analysis and creation of a media library. The next lesson we offer future educators the questionnaire of motives for education and pedagogical activity.

To achieve the purpose of the research the complex methods were used:

- theoretical: the study, theoretical analysis and generalization of scientific ideas in the pedagogical, psychological, philosophical literature on the problem of the formation of the pedagogical consciousness of future university educators in order to identify different points of view on this problem;

- empirical: observation, questioning, testing, self-assessment, expert assessment, analysis of the level of pedagogical consciousness development of future university educators, pedagogical experiment, which helped to obtain the necessary data as to the signs of pedagogical consciousness formation at different stages of its development;

- statistical: processing the results of an experimental study; qualitative and quantitative analysis of experimental indicators.

Summarizing the theoretical principles to the definition, the content and the structure of pedagogical consciousness, we distinguish criteria and indicators of its formation (Table 1). 
Table 1. The value of criteria and indicators of pedagogical consciousness formation of future university educators in the process of teaching English

\begin{tabular}{|l|l|}
\hline Criteria & Indicators \\
\hline $\begin{array}{l}\text { Content and } \\
\text { activity }\end{array}$ & $\begin{array}{l}\text { professional knowledge and skills, the concept of } \\
\text { pedagogical consciousness, characteristics of the } \\
\text { pedagogical consciousness, the methods of } \\
\text { healthy psychological climate formation. }\end{array}$ \\
\hline $\begin{array}{l}\text { Motivation } \\
\text { and value }\end{array}$ & $\begin{array}{l}\text { Values and value orientations, professionally } \\
\text { significant qualities of the future university } \\
\text { educator, motivation of professional } \\
\text { self-improvement, emotional and valuable } \\
\text { attitude towards oneself }\end{array}$ \\
\hline $\begin{array}{l}\text { Evaluation } \\
\text { and } \\
\text { reflection }\end{array}$ & $\begin{array}{l}\text { Self-esteem, level of career advancement, } \\
\text { self-control, self-regulation. }\end{array}$ \\
\hline
\end{tabular}

\section{Results}

The efficiency of the organization and methodical conditions of pedagogical consciousness formation of future university educators in the process of teaching English was ensured due to the use of integrity and close interconnection of all its criteria. The control of the efficiency of the formative experiment on the introduction in the pedagogical process of teaching English of organizational and methodological conditions of pedagogical consciousness formation of future university educators was implemented by means of the diagnostic complex described above in accordance with the key criteria of the pedagogical consciousness formation: content and activity, motivation and value, evaluation and reflection. We got the following results.

According to the content and activity criterion on the relevant indicators, we identified: a high level of theoretical knowledge and practical skills formation by the method of expert assessments and using a specialized questionnaire that is $9 \%$ higher in EG than in CG $(55 \%$ and $46 \%$, respectively); a high level of formation of ideas about the key characteristics of the pedagogical consciousness that is $58 \%$ in EG and $52 \%$ in CG; a high level of ability to create a healthy psychological climate in the group diagnosed $56 \%$ in EG and $51 \%$ in CG. Thus, we diagnosed better results in the experimental group than in the control one. In addition, the dynamics of increasing the level of the pedagogical consciousness formation in $\mathrm{EG}$ at the end of the formative experiment regarding the ascertaining one are positive. The number of students with a low level of the pedagogical consciousness formation was decreased by $9 \%$ in $\mathrm{EG}$ and $4 \%$ in $\mathrm{CG}$ and the number of students with a high level of pedagogical consciousness formation was increased on $8 \%$ in EG and $3 \%$ in $\mathrm{CG}$.

As to motivation and value criterion we determined a high level of formation of values and value orientations by the humanistic orientation test (Friedman, \& MacDonald, $2006)$ that is $5 \%$ higher in EG than in CG (55\% and $50 \%)$ and by the questionnaire measuring spiritual needs (Bryant, Wickliffe, Mayhew \& Behringer, 2009) that is $57 \%$ in $\mathrm{EG}$ and $52 \%$ in CG. These results confirm the results fixed by the author's diagnostic method to identify the significance of indicators of pedagogical consciousness concerning spiritual and moral norms. A high level of formation of the professionally essential qualities assessed by the expert and self-assessment test is $58 \%$ in EG and $52 \%$ in CG. We revealed that ethical values (spirituality, morality, the culture of feelings, restraint, discipline, diligence, self-control, etc.) are prevailing. A high level of the motives of raising the level of pedagogical consciousness assessed by the questionnaire (Abraham, Shirrell, Downs-Tepper, \& Chakravarthy, 2015) is $56 \%$ in EG and $48 \%$ in CG. The results show a high level of motivated professional self-improvement, which is deeply realized. The study of the emotion and value relation to oneself and one's education and profession oriented activity shows that $58 \%$ students of EG and $49 \%$ of $\mathrm{CG}$ correspond to adequate self-esteem, the assessment of pedagogical phenomena on the scientific basis. Thus, according to the main indicators of motivation and value criterion that affirm a high level of pedagogical consciousness formation we got better higher results in EG than in CG. In addition, the dynamics of the increase of the level of pedagogical consciousness formation are positive. The number of students with a low level of pedagogical consciousness formation is decreased by $9 \%$ in EG and only by $4 \%$ in $\mathrm{CG}$, and the number of students with high level of formation is increased by $10 \%$ in $\mathrm{EG}$ and by $6 \%$ in $\mathrm{CG}$.

According to the evaluation and reflection criterion we fixed the following results: adequate self-esteem of the students is $8 \%$ higher in EG than in CG $(58 \%$ EG and $50 \%$ CG, respectively). The expert test confirms the adequate students' self-esteem and the optimal understanding of the professional abilities, which is an important factor in personal development. A high level of career aspiration formation which is $58 \%$ in EG and $49 \%$ in $\mathrm{CG}$ characterizes personality maturity, adequate and realistic idea of one's abilities, the ability to assess and plan one's activity correctly. Thus, in terms of the main indicators that give evidence to a high level of pedagogical consciousness formation, according to an evaluation and reflection criterion, we diagnosed better results in the experimental group, the dynamics of increasing the level of the pedagogical consciousness formation in EG being positive. The number of students with a low level of pedagogical consciousness formation is decreased by $19 \%$ in EG, and only by $12 \%$ in CG. The number of students with a high level of pedagogical consciousness formation is increased by $9 \%$ in $\mathrm{EG}$, and by $3 \%$ in $\mathrm{CG}$.

The generalized results of the experiment for each criterion are presented in table 2. (Table 2). 
Table 2. Levels of formation of the pedagogical consciousness of future university teachers after the formative experiment, (\%)

\begin{tabular}{|c|c|c|c|c|c|c|c|c|c|}
\hline \multirow{2}{*}{ Groups } & \multicolumn{2}{|c|}{ Content and activity criterion } & \multicolumn{2}{|c|}{ Motivation and value criterion } & \multicolumn{3}{|c|}{$\begin{array}{c}\text { Evaluation and reflection } \\
\text { criterion }\end{array}$} \\
\cline { 2 - 10 } & $\mathrm{H}$ & $\mathrm{S}$ & $\mathrm{L}$ & $\mathrm{H}$ & $\mathrm{S}$ & $\mathrm{L}$ & $\mathrm{H}$ & $\mathrm{S}$ & $\mathrm{L}$ \\
\hline The control group (CG) & $47 \%$ & $48 \%$ & $5 \%$ & $50 \%$ & $47 \%$ & $3 \%$ & $42 \%$ & $47 \%$ & $9 \%$ \\
\hline The experimental group (EG) & $53 \%$ & $45 \%$ & $2 \%$ & $54 \%$ & $44 \%$ & $2 \%$ & $47 \%$ & $51 \%$ & $2 \%$ \\
\hline
\end{tabular}

The experimental data confirm the hypothesis that the pedagogical consciousness formation of future university educators in the process of teaching English can be effective by creating the organizational and methodological conditions in the pedagogical process.

The obtained results show that due to the introduction of these conditions, there was enhancement in the formation of spiritual, moral and cultural values, professionally significant qualities, positive motivation towards the future pedagogical activity and the effectiveness in fulfillment responsibilities.

The conformity of the program of the special course with the knowledge elements of content and activity component promoted to the professional knowledge formation. Positive changes in the priorities of the values corresponding pedagogical consciousness of university teachers were achieved by using diagnostic tools in combination with the educational influence of the moderator's interactive activity on students. The formation of an integrated system of acquired knowledge and values of students' consciousness was fostered by the formation by a comprehensive systematic pedagogical impact in the process of implementing the organization and methodological conditions as a whole. The use of a large number of various exercises and training encouraged the formation of the necessary professional and significant personal qualities. Self-control and self-regulation skills were acquired by students in the process of mastering relevant techniques in the process of applying appropriate diagnostic tools and active contacts between students under moderator's guidance. Techniques of a favorable psychological climate in the group, as well as the norms of the culture of pedagogical communication and morality, were mastered by students on a theoretical level, the use of interactive teaching methods, situational tasks created the conditions for developing practical skills for applying these methods in practice. The development of intelligence and creativity of professional-oriented activities was facilitated by a combination of theoretical material with a variety of tasks of different levels of complexity, primarily of a creative nature. The active use of a variety of works of art and folk art as didactic means contributed to the development of spirituality as one of the most important manifestations of pedagogical consciousness.

A striking example of changes in students' judgments was provided by the creative interaction of the teacher, the carrier of humanistic values and the student through active forms of educational training, creative exercises, and dialogue. Before the formative experiment, many students could not formulate the reason for the choice of the teaching profession; some students limited the purpose of future professional activity to knowledge transfer. After the formative experiment, such judgments dominated: «During the interactive exercises I learned about the new facets of my future teaching profession I didn't even guess», «The teacher's job is my "cherish" dream. I like to teach, to pass not only knowledge but also experience, not only to teach but also to educate future specialists».

The obtained results testify to the significant effect of the pedagogical influence of the organization and methodological conditions on students in order to form a value related to study at higher school, spiritual and moral norms, the significance of creativity, awareness of reflexivity and dialogue in future pedagogical activity. Enhanced training activities in the form of interactive games and exercises, discussions, solution of situational tasks have positively influenced on the formation of ethical values and ethical behavior, which is extremely important, since the assessment of the morality of the act is characterized primarily not by the presence of ethical knowledge, but by the ability to apply it correctly in any situation. But a small percentage of the low level of these issues (3\% of masters of EG and 6\% of EG) indicates that there are such representations of value orientations which are not always properly implemented in the activity, and also confirm the limited capacity of the organization and methodological conditions when applied it in teaching only a separate academic discipline and with the predominance of the subject orientation of the professional training of future specialists as a whole.

\section{Discussion}

Highly relevant for our study is the claim, proven by researchers (Rochat, 2018; Sokolov, Chernorizov, 2013), that pedagogical consciousness is not only caused by genetic factors, but it can be formed. It confirms our finding of the feasibility for the pedagogical consciousness formation through teaching and educating. Our findings and other studies present evidence that the educational environment for future university educators teaching and education is the safeguard of the possibility to raise pedagogical consciousness. Bürgener and Barth stress that "open learning environments pursue situated 
learning, particularly facilitating the development of content knowledge as well as pedagogical content knowledge" (2018, 824 p.).

As the purpose of our research is pedagogical consciousness formation through teaching English, efficient interaction in the process of teaching English with the use of different forms of interactive activities is applied to facilitate the development of its main characteristics, namely spirituality, morality, the culture of feelings, creativity, reflexivity, dialogue, intellectuality. We address to such interactive activities which are included in the author special course with regard to emerging particular cognitive concern to foreign language and its integration with the development of professional values and personal qualities, professional knowledge and skills of future specialists. Such activity has its objective and is distinct from the traditional one. It is confirmed with the findings of Stavitska (2017) which also proved the effectiveness to stimulate students' motivation to gain knowledge, skills and experience in their professional field through English and active use of multimedia to provide the greatest possible cognitive activity. Lytovchenko, Ogienko, Sbruieva, Sotska, (2018) found the positive effects of the application of interactive methods and technologies, Task-Based Learning and Project-Based Learning in teaching English. Cinkara also found "positive effect of using video-stimulated recall technique as a method of motivating language learners to reflect on their oral production tasks" (2016, p.694). The finding of Liao et al. also confirms that "creativity technique pedagogy significantly improved learners' English learning performance, creativity, and learning motivation" (2018, 213 p.). It correlates with our findings that pedagogical consciousness formation through teaching English can be effective when using educational training, interactive games, role plays and exercises, solution of situational tasks while modelling conditions of professional content, discussions, "round tables", seminars, conferences, a variety of works of art and folk art having great impact on personality' comprehensive development.

Another proof for the pedagogical consciousness development of future university educators in the sphere of literature and arts is acquiring a foreign language. Our study is confirmed by the findings of other researchers that studying English promotes fostering creative abilities of students, fluency of thought, originality, flexibility, the desire for intellectual novelty. Jiang, Ouyang and Liu proved a positive correlation between acquiring foreign language and analytic thinking, the degree of cognitive complexity and degree of thinking activeness (2016). Harizaj and Hajrulla (2017) proved the use of information-gap activities, role-plays, simulation and jigsaw activities, surveys, interviews in teaching English to develop student's critical thinking. Sharma, Ahuja and Satsangee offer evidence how literature participate with other forms of culture and with human biology to produce experiences of self-conscious awareness (2016, 228 p.). It correlates with our findings of the cultural aspect of language that literature and arts as well as acquiring a foreign language reflects human consciousness and shapes it.

The definition of the essence and structure of pedagogical consciousness as a systemic phenomenon has opened up us the opportunity to identify the effective pedagogical conditions for its formation, criteria, and indicators that adequately reflect the level of its formation. This allowed us to create the conditions for pedagogical consciousness formation not as a set of methods, and tasks offered by the other authors but the conditions corresponding pedagogical consciousness structure that provided positive effects proved by the results of the experiment. In addition, the organization and methodological conditions, developed by us, in contrast to previous studies by other authors, proved to be universal enough to go beyond the scope of the professionally oriented disciplines and to be used for a particular academic discipline, English in this case.

As the processes of consciousness enrichment in language is unbounded it is quite obvious that the organization and methodological conditions cannot fully ensure the pedagogical consciousness formation. Thought our research revealed the effectiveness of pedagogical consciousness formation certain limitations should be specified. One is the short period of experimental research for one semester. A future study might consider the whole period of teaching English at the university as professional knowledge and skills as well as qualitative characteristics of pedagogical consciousness and personal qualities of future educators are certain to develop and improved with the period of study. Future search might focus on using a supplementary diagnostic tool to reveal more qualitative data.

\section{Conclusions}

As a result of the study, we proposed a refined definition of the pedagogical consciousness of a future university educator as an integrative, complex, multilevel, systemic, dynamic, personal entity that includes approaches to its definition, criteria and its indicators, qualitative characteristics of pedagogical consciousness and personal qualities of the future university educator, which directly influence his development, encouraging him to carry out concrete actions, giving them an assessment.

The conditions of the pedagogical consciousness formation in the educational process are reflected in: the training program of theoretical knowledge on the nature and the structure of pedagogical consciousness; ensuring the active learning activities of students to develop the 
skills of practical application of important pedagogical tools and methodologies; the use of interactive teaching methods to create a learning environment that contributes to the assimilation of moral, ethical and cultural values of pedagogical activity as well as the mastering of the self-assessment skills and self-control of the level of pedagogical consciousness formation. In practice, the conditions applied can be successfully realized by introducing in the process of teaching English the special course and the diagnostic complex.

\section{REFERENCES}

[1] Abraham, R., Shirrell, S., Downs-Tepper, H., \& Chakravarthy, H. (2015). Quantitative assessment of teacher motivation, classroom practices, and student learning. Retrieved May, 10, 2016 from: http://idinsight.org/insights/stir/STIR\%20Baseline\%20Rep ort \%20Final\%20Clean.pdf

[2] Albulescu, I., \& Albulescu, M. (2014). The University in the community. The university's contribution to local and regional development by providing educational services for adults, Procedia - Social and Behavioral Sciences, 142, 5 -https://doi.org/10.1016/j.sbspro.2014.07.578

[3] Archibald, S., Coggshell, J., Croft, A., \& Goe, L. (2011). High Quality Professional Development For All Teachers: Effectively Allocating Resources. Chicago, IL: National Comprehensive Center for Teachers Quality. Retrieved August 15, 2018 from: http://www.gtlcenter.org/sites/default/files/docs/HighQuali tyProfessionalDevelopment.pdf

[4] Bak, H. (2018). Beyond the economy: Education for development. Kasetsart Journal of Social Sciences. https://doi.org/10.1016/j.kjss.2018.06.001

[5] Blašková, M., Blaško, R., \& Kucharčíková, A. (2014). Competences and Competence Model of University Teachers. Procedia - Social and Behavioral Sciences, 159, 457-467.https://doi.org/10.1016/j.sbspro.2014.12.407.

[6] Bryant, A. N., Wickliffe, K., Matthew J Mayhew, M. J., \& Behringer, L. B. (2009) Developing an Assessment of College Students' Spiritual Experiences: The Collegiate Religious and Spiritual Climate Survey. Journal of College and Character, 10(6), 1-10. https://doi.org/10.2202/1940-1639.1452

[7] Bürgener, L., \&Barth, M. (2018). Sustainability competencies in teacher education: Making teacher education count in everyday school practice. Journal of Cleaner Production, 174, 821-826. https://doi.org/10.1016/j.jclepro.2017.10.263

[8] Cinkara E. (2016). Reflective practice and foreign language classroom anxiety: video-stimulated recall at work. Reflective Practice, 17(6), 694-707. https://doi.10.1080/14623943.2016.1206880

[9] Dearden, J. (2014). English as a medium of instruction - a growing global phenomenon. London: British Council. $\begin{array}{llll}\text { Retrieved August } & 17, & 2018 \text { from: }\end{array}$ https://www.britishcounc

il.org/sites/default/files/e484_emi_-_cover_option_3_final _web.pdf

[10] Dearden, J., \& Macaro, E. (2016). Higher education teachers' attitudes towards English medium instruction: A three-country comparison. Studies in Second Language Learning and Teaching, 6(3), 455-486. http://doi.org/10.14746/sllt.2016.6.3.5

[11] Dumciuviene, D. (2015). The Impact of Education Policy to Country Economic Development. Procedia - Social and Behavioral Sciences, 191, 2427 - 2436. https://doi.org/10.1016/j.sbspro.2015.04.302

[12] Duta, N., Tomoaicaa, E., \& Panisoara, G. (2015). Desirable characteristics defining to describe an effective teacher. Procedia - Social and Behavioral Sciences, 197. 1223 1229. doi: 10.1016/j.sbspro.2015.07.383

[13] Ebadi, S., \&Gheisari, N. (2016). The role of consciousness-raising through critical reflection in teachers' professional development: A sociocultural perspective. Cogent Education, 3(1), 1147990. https://doi.org/10.1080/2331186X.2016.1147990

[14] Enns, E., \& Shapovalova, M. (2015). Psycho-Pedagogical Model of Students' Professional Consciousness Development. Procedia - Social and Behavioral Sciences, 214,385-392 .https://doi.org/10.1016/j.sbspro.2015.11.670

[15] European Commission. (2017). Communication from the Commission to the European Parliament, the Council, the European Economic and Social Committee and the Committee of the Regions Strengthening European identity through Education and Culture the European Commission's contribution to the Leaders' meeting in Gothenburg. Retrieved August, 18,2018 from: https:/ec.europa.eu/education/sites/education/files/he-com -2017-247_en.pdf

[16] Friedman, H. L., \&MacDonald, D. A. (2006). Humanistic Testing and Assessment. Journal of Humanistic $\begin{array}{lllr}\text { Psychology, } & 46 & \text { (4), } & 510-529 .\end{array}$ https://doi.org/10.1177/002216780629021

0. Retrieved May, 10, 2016 from: https://www.researchgate.net/publication/247719409/down load

[17] Gay, G., \&Kirkland, K. N. (2003). Developing Cultural Critical Consciousness and Self-Reflection in Preservice Teacher Education. Theory into Practice, 42(3).181 187. https://doi: 10.1353/tip.2003.0029

[18] Harizaj M. \& Hajrulla V. (2017). Fostering Learner's Critical Thinking Skills in EFL: Some Practical Activities European Scientific Journal, 29(13) http://dx.doi.org/10.19044/esj.2017.v13n29p126

[19] Jiang, J., Ouyang, J., \& Liu, H. (2016). Can Learning a Foreign Language Foster Analytic Thinking? - Evidence from Chinese EFL Learners' Writings. PloS one, 11(10), https://doi.10.1371/journal.pone.0164448

[20] Karpushyna, M., Bloshchynskyi, I., Nakonechna, A., Skyba, K. "Creating Meaningful Foreign Language Environment by Means of Content-based Starters." Universal Journal of Educational Research 7.12 (2019) 2710 - 2716. doi: 10.13189/ujer.2019.071219.

[21] Kalsoom, Q., \& Khanam, A. (2017). Inquiry into 
sustainability issues by preservice teachers: A pedagogy to enhance sustainability consciousness. Journal of Cleaner Production, 164, 1301-1311 https://doi.org/10.1016/j.jclepro.2017.07.047

[22] Kostiainen, E., Ukskoski, T., Ruohotie-Lyhty, M., Kauppinen, M., Kainulainen, J., \& Makinen, T. (2018). Meaningful learning in teacher education. Teaching and Teacher Education, 66-77. https://doi.org/10.1016/j.tate.2017.12.009

[23] Kuyumcu, F.N. (2012). The importance of "Art Education" courses in the education of prospective teachers. Procedia Social and Behavioral Sciences,51. 474 - 479. https://doi: 10.1016/j.sbspro.2012.08.192

[24] Liao, Yu-H., Chen, Yi-L., Chen, H.-Ch., \&Chang, Yu-L. (2018). Infusing creative pedagogy into an English as a foreign language classroom: Learning performance, creativity, and motivation. Thinking Skills and Creativity, 29, 213-223. https://doi.org/10.1016/j.tsc.2018.07.007

[25] Libet B. (1988) Consciousness: Conscious, Subjective Experience. In: States of Brain and Mind. Readings from the Encyclopedia of Neuroscience. Birkhäuser, Boston, MA. https://doi.org/10.1007/978-1-4899-6771-8_11

[26] Lytovchenko, I., Ogienko, O., Bruieva, A., Sotska, H., (2018). Teaching English for specific purposes to adult learners at university: methods that work, Advanced 10 , $69-75$ https://doi.org/10.20535/2410-8286.149741

[27] Margić, B., \&Vodopija-Krstanović, I. (2018). Language development for English-medium instruction: Teachers' perceptions, reflections and learning. Journal of English for Academic Purposes, 35, 31-41. https://doi.org/10.1016/j.jeap.2018.06.005

[28] McDonough, K. A. (2015). Performing Critical Consciousness in Teaching: Entanglements of Knowing, Feeling and Relating (2015). Doctoral Dissertations. 383. https://scholarworks.umass.edu/dissertations_2/383

[29] Neamtu, D. M. (2015). Education, the economic development pillar. Procedia - Social and Behavioral Sciences, $\quad 180$ 413-420. https://doi.org/10.1016/j.sbspro.2015.02.138

[30] Plögera, W., Scholla, D., \&Seifert, A. (2018). Bridging the gap between theory and practice - The effective use of videos to assist the acquisition and application of pedagogical knowledge in preservice teacher education. Studies in Educational Evaluation, 58, 197-204. https://doi.org/10.1016/j.stueduc.2017.12.009

[31] Radd, S., \& Macey, E. M. (2013). Developing critical consciousness through professional learning. Indianapolis, IN: Great Lakes Equity Center. Retrieved August,20, 2018 from

http://glec.education.iupui.edu/assets/files/CriticalConscio usnessBrief_FINAL_1_9 2014.pdf

[32] Rochat, P. (2018). The Ontogeny of Human Self-Consciousness. Current Directions in Psychological Science, $\quad 27 \quad$ (5), 345-350 https://doi.org/10.1177/0963721418760236

[33] Scott, C. L. (2015). The futures of learning 3: What kind of pedagogies for the 21st century? UNESCO Education
Research and Foresight, Paris. Retrieved June, 10, 2018from:http://unesdoc.unesco.org/images/0024/002431/ 243126e.pdf

[34] Serdenciuc, N. L. (2015). Shaping Learning Experiences of the Future Teachers. Procedia. Social and Behavioral Sciences, $\quad 180, \quad 966 \quad-\quad 971$. https://doi.org/10.1016/j.sbspro.2015.02.257

[35] Shabani, K. (2016). Applications of Vygotsky's sociocultural approach for teachers' professional development. Cogent Education,3(1), 1252177. https://doi.org/10.1080/2331186X.2016.1252177

[36] Sharma, S., Ahuja, S., \& Satsangee, D. (2016). A study of consciousness of university students in relation to the academic achievement and level of education. MIER Journal of Educational Studies, Trends \& Practices,6(1), 91-97. Retrieved August, 10, 2016 from: http://www.mierjs.in/ojs/index.php/mjestp/article/view/109 $/ 10$

[37] Sirswal, D. R. (2009). Glossary of philosophy of mind. Philosophical Mind Studies. Retrieved August, 10, 2018from:https://niyamak.wordpress.com/glossary-of-phil osophy-of-mind/

[38] Sokolov, E., Chernorizov, K. (2013). Psychophysiology of Consciousness. Oxford University Press.

[39] Stavytska, I. (2017). The formation of foreign language competence of engineering students by means of multimedia. Advanced Education, 7, 123-128. https://doi.org/10.20535/2410-8286.95301

[40] Steering Committee (2017). Meeting Report, 3rd Meeting of the SDG-Education 2030 Steering Committee. Retrieved August, 18, 2018 from: http://unesdoc.unesco.org/images/0025/002529/252973E. Pdf

[41] Sumara, D., Luce - Kapler, R., \& Iftody, T. (2013) Educating Consciousness through literary experiences. Complexity Theory and the Philosophy of Education, 40 (1),

$228-241$. https://doi.org/10.1111/j.1469-5812.2007.00408.x

[42] UNESCO (2013). Outcome document of the Technical Consultation on Global Citizenship Education: Global Citizenship Education - An Emerging Perspective. Retrieved August, 17, 2018 from: http://unesdoc.unesco.org/images/0022/002241/224115E.p df

[43] UNESCO (2015). Education 2030: Incheon Declaration and Framework for Action for the implementation of Sustainable Development Goal 4. Ensure inclusive and equitable quality education and promote lifelong learning opportunities for all. Retrieved August, 17, 2018from: http://unesdoc.unesco.org/images/0024/002456/245656E.p $\mathrm{df}$

[44] Sidash, N. (2017). Formuvannia pedahohichnoi svidomosti u maibutnikh vykladachiv vyshchoi shkoly [The pedagogical consciousness formation of future university teachers]. Unpublished PhD dissertation, Volodymyr Dahl East Ukrainian National University, Kyiv, Ukraine. 